\title{
Structure and Absolute Configuration of an Atrovenetin-like Metabolite from Aspergillus silvaticus
}

\author{
Koichi Homma, Keiichi Fukuyama,* Yukiteru Katsube, \\ Yasuo Kimura,** and Takashi HamaSAKI** \\ Faculties of Engineering and ${ }^{* *}$ Agriculture Tottori University, \\ Koyama, Tottori 680, Japan
}

Received December 27, 1979

\begin{abstract}
The structure and absolute configuration of a metabolite isolated from Aspergillus silvaticus was studied by an X-ray diffraction method. Crystals were orthorhombic, with space group $\mathrm{P} 2{ }_{1} 2_{1} 2_{1}$, and $a=9.894(5), b=6.803$ (4), $c=22.519$ (6) $\AA$, and $Z=4$. The structure was solved by a direct method and refined by a block-diagonal least-square method to $R=0.07$ for 1143 non-zero reflections. The metabolite was identified as naphthalic anhydride obtained from atrovenetin. The absolute configuration determined by the Bijvoet method is consistent with that shown chemically. The molecule has two intramolecular hydrogen bonds.
\end{abstract}

Although various kinds of metabolites have been isolated from the genus Aspergillus," little is known about the metabolites from Aspergillus silvaticus. During a survey of the metabolites of a strain of Aspergillus silvaticus Fennell and Raper IFO 8173, we isolated a pale yellow compound which shows blue fluorescence under ultraviolet light. The structure and absolute configuration of this metabolite were studied by an X-ray diffraction method. In this paper, we wish to report an investigation which identifies the metabolite as the naphthalic anhydride obtained from atrovenetin and which confirms the configuration shown by a chemical study.<smiles>Cc1cc(O)c2c3c(C(=O)OC(=O)O)c(O)c4c(c13)O[C@@](C)([C@@H]4C)C2(C)C</smiles>

\section{EXPERIMENTAL}

Isolation. This mold was grown as a surface cul-

* To whom correspondence should be addressed. ture on malt extract medium at $24^{\circ} \mathrm{C}$. After 3 weeks, the mycelial mats were harvested. The dried mycelial mats were extracted with acetone. The acetone extract was chromatographed on a column of silicic acid. The eluate with benzene gave a crystalline solid which was recrystallized from acetone to afford pale yellow needles, mp $262 \sim 263^{\circ} \mathrm{C},[\alpha]_{\mathrm{D}}^{19}+75^{\circ}(c=1.0, \mathrm{EtOH})$, Anal. Found: $\mathrm{C}, 65.71 ; \mathrm{H}, 4.85$; Calcd. for $\mathrm{C}_{18} \mathrm{H}_{18} \mathrm{O}_{8}$ : $\mathrm{C}, 65.85 ; \mathrm{H}, 4.91 \%$. NMR $\left(\mathrm{CDCl}_{3}, 60 \mathrm{MHz}\right) \delta: 1.31$ $(3 \mathrm{H}, \mathrm{s}), 1.50(3 \mathrm{H}, \mathrm{d}, J=7 \mathrm{~Hz}), 1.55(3 \mathrm{H}, \mathrm{s}), 2.80(3 \mathrm{H}, \mathrm{s})$, $4.80(1 \mathrm{H}, \mathrm{q}, J=7 \mathrm{~Hz}), 6.75(1 \mathrm{H}, \mathrm{s}), 11.18(1 \mathrm{H}, \mathrm{s}), 11.50$ $(1 \mathrm{H}, \mathrm{s})$.

Crystal data. $\quad \mathrm{C}_{18} \mathrm{H}_{18} \mathrm{O}_{6}, M=328.3$, orthorhombic, space group $\mathrm{P} 2{ }_{1} 2_{1} 2_{1}$ from systematic absences, $a=$ 9.894 (5), $b=6.803$ (4), $c=22.519$ (6) $\AA, V=1515.7 \AA^{3}$, $Z=4, D_{m}=1.43 \mathrm{~g} \cdot \mathrm{cm}^{-3}, D_{x}=1.44 \mathrm{~g} \cdot \mathrm{cm}^{-3}$.

Crystallographic measurement. Photographic investigation showed the crystals to be orthorhombic and the space group to be $\mathrm{P}_{1} 2_{1} 2_{1}$. The unit cell constants and intensities were measured on a Rigaku four-circle diffractometer using $\mathrm{Ni}$-filtered $\mathrm{Cu}-K \alpha$ radiation. The intensities of the independent reflections up to $2 \theta=$ $127^{\circ}$ were measured by means of a $\theta-2 \theta$ scan method. The scan range was calculated as $1.0^{\circ}+0.15^{\circ} \tan \theta$ and scan speed was $4^{\circ} \mathrm{min}^{-1}$ in $2 \theta$. The background was counted for $8 \mathrm{~s}$ at each end of the scan range. After correction for the Lorentz and polarization factors, 1145 of the 1457 refiections were considered to be observed and used for subsequent structure analysis.

Structure determination and refinement. The structure was deduced by MULTAN ${ }^{2)}$ followed by successive Fourier synthesis. At the early stage of the refinement, the coordinates and isotropic temperature factors were 
Table I. Final Atomic Parameters $*\left(\times 10^{4}\right)$ of Non-hydrogen Atoms, with Estimated Standard Deviations

\begin{tabular}{rrrrrrrrrr}
\hline & \multicolumn{1}{c}{$x$} & \multicolumn{1}{c}{$y$} & \multicolumn{1}{c}{$z$} & \multicolumn{1}{c}{$\beta_{11}$} & \multicolumn{1}{c}{$\beta_{22}$} & \multicolumn{1}{c}{$\beta_{33}$} & \multicolumn{1}{c}{$\beta_{12}$} & \multicolumn{1}{c}{$\beta_{13}$} & \multicolumn{1}{c}{$\beta_{23}$} \\
\hline $\mathrm{C}(1)$ & $5084(8)$ & $9550(10)$ & $3400(3)$ & $220(10)$ & $192(14)$ & $19(1)$ & $-57(26)$ & $2(6)$ & $-2(8)$ \\
$\mathrm{C}(2)$ & $5473(7)$ & $9605(9)$ & $2775(2)$ & $175(8)$ & $129(11)$ & $17(1)$ & $-31(22)$ & $-28(5)$ & $5(7)$ \\
$\mathrm{C}(3)$ & $6818(6)$ & $9543(10)$ & $2616(3)$ & $141(7)$ & $182(13)$ & $25(1)$ & $60(22)$ & $-40(5)$ & $-20(9)$ \\
$\mathrm{C}(4)$ & $7188(6)$ & $9571(11)$ & $2025(3)$ & $96(6)$ & $304(17)$ & $27(1)$ & $-9(24)$ & $-22(5)$ & $13(10)$ \\
$\mathrm{C}(5)$ & $6262(5)$ & $9552(10)$ & $1581(3)$ & $85(6)$ & $240(14)$ & $23(1)$ & $-21(21)$ & $-8(5)$ & $19(9)$ \\
$\mathrm{C}(6)$ & $4849(5)$ & $9574(9)$ & $1725(2)$ & $116(6)$ & $167(11)$ & $15(1)$ & $41(9)$ & $-3(4)$ & $-3(7)$ \\
$\mathrm{C}(7)$ & $3752(5)$ & $9511(9)$ & $1314(2)$ & $94(5)$ & $174(11)$ & $15(1)$ & $21(19)$ & $6(4)$ & $-17(7)$ \\
$\mathrm{C}(8)$ & $2669(6)$ & $9223(10)$ & $426(2)$ & $119(7)$ & $313(18)$ & $16(1)$ & $-22(22)$ & $-8(5)$ & $-4(8)$ \\
$\mathrm{C}(9)$ & $1537(6)$ & $9496(11)$ & $904(2)$ & $115(7)$ & $288(15)$ & $18(1)$ & $96(22)$ & $-15(4)$ & $-49(9)$ \\
$\mathrm{C}(10)$ & $2434(6)$ & $9477(9)$ & $1468(2)$ & $96(6)$ & $247(14)$ & $17(1)$ & $-38(22)$ & $4(4)$ & $-22(8)$ \\
$\mathrm{C}(11)$ & $2034(6)$ & $9484(11)$ & $2057(2)$ & $113(7)$ & $260(15)$ & $20(1)$ & $65(22)$ & $8(5)$ & $5(9)$ \\
$\mathrm{C}(12)$ & $3078(6)$ & $9544(11)$ & $2493(2)$ & $154(8)$ & $232(14)$ & $17(1)$ & $31(23)$ & $23(5)$ & $-8(8)$ \\
$\mathrm{C}(13)$ & $2696(7)$ & $9536(11)$ & $3107(3)$ & $201(10)$ & $281(16)$ & $18(1)$ & $-26(32)$ & $24(6)$ & $-12(9)$ \\
$\mathrm{C}(14)$ & $4441(6)$ & $9570(9)$ & $2330(2)$ & $133(6)$ & $119(10)$ & $17(1)$ & $51(21)$ & $-6(4)$ & $8(7)$ \\
$\mathrm{C}(15)$ & $6708(7)$ & $9608(14)$ & $934(3)$ & $107(6)$ & $512(25)$ & $25(1)$ & $28(27)$ & $35(5)$ & $35(12)$ \\
$\mathrm{C}(16)$ & $2657(8)$ & $10772(18)$ & $-92(3)$ & $163(10)$ & $713(38)$ & $25(2)$ & $119(42)$ & $-5(7)$ & $106(14)$ \\
$\mathrm{C}(17)$ & $777(9)$ & $11417(16)$ & $850(3)$ & $168(11)$ & $673(36)$ & $23(2)$ & $146(37)$ & $-6(7)$ & $-32(13)$ \\
$\mathrm{C}(18)$ & $600(8)$ & $7714(11)$ & $873(4)$ & $171(10)$ & $327(21)$ & $34(2)$ & $-192(27)$ & $-45(8)$ & $-4(11)$ \\
$\mathrm{O}(1)$ & $3730(5)$ & $9574(7)$ & $3528(2)$ & $220(7)$ & $291(11)$ & $14(1)$ & $9(20)$ & $16(4)$ & $4(6)$ \\
$\mathrm{O}(2)$ & $5860(6)$ & $9581(8)$ & $3811(2)$ & $282(9)$ & $320(12)$ & $18(1)$ & $-25(24)$ & $-60(5)$ & $8(7)$ \\
$\mathrm{O}(3)$ & $7820(5)$ & $9526(9)$ & $3021(2)$ & $179(7)$ & $382(14)$ & $33(1)$ & $-30(22)$ & $-78(5)$ & $8(8)$ \\
$\mathrm{O}(4)$ & $3966(4)$ & $9539(7)$ & $722(1)$ & $102(4)$ & $319(10)$ & $14(1)$ & $21(14)$ & $2(3)$ & $17(6)$ \\
$\mathrm{O}(5)$ & $743(4)$ & $9474(9)$ & $2197(2)$ & $103(4)$ & $515(17)$ & $27(1)$ & $-23(19)$ & $38(4)$ & $-21(9)$ \\
$\mathrm{O}(6)$ & $1539(5)$ & $9513(10)$ & $3300(2)$ & $208(7)$ & $476(17)$ & $22(1)$ & $37(24)$ & $57(4)$ & $-14(8)$ \\
\hline & $*$
\end{tabular}

* Anisotropic temperature factors are in the form: $\exp \left[-\left(\beta_{13} h^{2}+\beta_{22} k^{2}+\beta_{33} l^{2}+\beta_{12} h k+\beta_{13} h l+\beta_{23} k l\right)\right]$.

refined by a block-diagonal least-squares method ${ }^{3)}$ by use of the carbon scattering factors. The atomic species were identified by temperature factors and the bond characters were assigned on the basis of bond lengths and angles. The two strongest reflections, 002 and 020 , were omitted from the calculation. Except for the hydrogen atoms bonded to $C(16)$, all the hydrogen atoms were located on the difference electron density map. The refinement with anisotropic temperature factors for non-hydrogen atoms and isotropic temperature factors for hydrogen atoms reduced the $R$ value to 0.07 for 1143 non-zero reflections, where the following weighting scheme was used: $w=1.0$ for $0<F_{0} \leqq 10$ and $w=\left[1.0+0.24\left(F_{0}-10\right)\right]^{-1}$ for $10<F_{0}$. The final atomic parameters are listed in Tables $I$ and II. A list of the observed and calculated structure factors is available from the authors on request.

Absolute configuration. The absolute configuration was examined by the Bijvoet method by utilizing the anomalous scattering of light atoms for $\mathrm{Cu}-\mathrm{K \alpha}$ radiation. ${ }^{4,5)}$ The 16 sets of Bijvoet and reference reflections with large $B A_{t \mathrm{th}}$ and with relatively large intensities were chosen by a computer program. A crystal with an approximate size of $0.2 \times 0.4 \times 0.2 \mathrm{~mm}$ was mounted with the $\mathrm{b}$ axis parallel to the $\phi$ axis of the
Table II. Final Atomic CoOrdinates $\left(\times 10^{3}\right)$ AND ISOTROPIC TEMPERATURE FACTORS $(\times 10)$ of Hydrogen Atoms*, with Estimated STANDARd DEVIATIONS

\begin{tabular}{lrrrr} 
& \multicolumn{1}{c}{$x$} & \multicolumn{1}{c}{$y$} & \multicolumn{1}{c}{$z$} & \multicolumn{1}{c}{$B / \AA^{2}$} \\
\hline $\mathrm{H}(\mathrm{O} 3)$ & $732(7)$ & $1021(12)$ & $329(3)$ & $57(19)$ \\
$\mathrm{H}(\mathrm{C} 4)$ & $829(7)$ & $962(12)$ & $191(3)$ & $52(18)$ \\
$\mathrm{H}(\mathrm{C} 15)$ & $642(8)$ & $1085(12)$ & $71(3)$ & $58(20)$ \\
$\mathrm{H}(\mathrm{C} 15)$ & $641(7)$ & $850(11)$ & $70(3)$ & $46(18)$ \\
$\mathrm{H}(\mathrm{C} 15)$ & $755(7)$ & $933(11)$ & $91(3)$ & $50(17)$ \\
$\mathrm{H}(\mathrm{C} 8)$ & $274(8)$ & $770(11)$ & $25(3)$ & $53(19)$ \\
$\mathrm{H}(\mathrm{C} 17)$ & $27(7)$ & $1125(11)$ & $50(3)$ & $46(17)$ \\
$\mathrm{H}(\mathrm{C} 17)$ & $141(7)$ & $1247(10)$ & $76(3)$ & $46(18)$ \\
$\mathrm{H}(\mathrm{C} 17)$ & $35(7)$ & $1176(10)$ & $118(3)$ & $45(17)$ \\
$\mathrm{H}(\mathrm{C} 18)$ & $10(7)$ & $771(10)$ & $52(3)$ & $42(17)$ \\
$\mathrm{H}(\mathrm{C} 18)$ & $-10(7)$ & $769(11)$ & $120(3)$ & $50(18)$ \\
$\mathrm{H}(\mathrm{C} 18)$ & $120(8)$ & $639(11)$ & $85(3)$ & $50(18)$ \\
$\mathrm{H}(\mathrm{O} 5)$ & $59(7)$ & $994(11)$ & $261(3)$ & $49(18)$ \\
\hline
\end{tabular}

* The methyl hydrogens bonded to carbon 16 are not included.

diffractometer. Careful intensity measurement for Bijvoet pairs and their reference-reflection pairs were made alternately 10 times. Experimental conditions for the Bijvoet measurement were essentially the same 
Table III. Results of the Bijvoet Measurement

$B A_{\text {ex }}{ }^{*}$ is the Mean Values of 10 Individual $B A$ 's. $B A_{\mathrm{th}}, B A_{\mathrm{ex}}$ ARE GIVEN IN \%

\begin{tabular}{rrrrrrrrr}
\hline$h_{1}$ & $k_{1}$ & $l_{1}$ & $h_{2}$ & $k_{2}$ & \multicolumn{1}{c}{$l_{2}$} & $B A_{\text {th }}$ & $B A_{\text {ex }}$ & DELA \\
\hline 1 & 1 & 7 & 1 & 1 & 9 & 1.06 & 2.21 & 2.08 \\
2 & 2 & 10 & 2 & 2 & 11 & 2.40 & 0.74 & 0.31 \\
2 & 2 & 5 & 3 & 2 & 5 & 1.17 & 4.16 & 3.56 \\
1 & 1 & 7 & 1 & 1 & 8 & 1.62 & 1.44 & 0.89 \\
3 & 2 & 4 & 4 & 2 & 4 & -2.08 & -0.31 & 0.15 \\
2 & 2 & 5 & 2 & 2 & 6 & 2.77 & 6.53 & 2.34 \\
4 & 1 & 10 & 4 & 1 & 11 & 0.73 & 1.47 & 2.00 \\
3 & 2 & 5 & 3 & 2 & 7 & -0.89 & 0.59 & -0.33 \\
2 & 1 & 2 & 2 & 1 & 1 & 0.79 & -0.22 & -0.28 \\
3 & 3 & 8 & 4 & 3 & 8 & 1.57 & 5.56 & 3.54 \\
3 & 1 & 10 & 5 & 1 & 10 & -1.43 & -0.10 & 0.07 \\
3 & 1 & 5 & 2 & 1 & 5 & 3.95 & 0.28 & 0.07 \\
4 & 2 & 1 & 5 & 2 & 1 & 2.08 & 7.49 & 3.61 \\
2 & 1 & 2 & 2 & 1 & 3 & 3.77 & -0.67 & -0.18 \\
5 & 1 & 4 & 3 & 1 & 4 & 2.47 & -4.75 & -1.93 \\
5 & 2 & 2 & 5 & 2 & 1 & 1.95 & 0.61 & 0.31 \\
\hline
\end{tabular}

* The notations are same as those in Engel's paper.4)

$\mathrm{DELA}=B A_{\mathrm{\theta X}} / B A_{\mathrm{tb}}, B A=\left(Q_{\mathrm{H}_{1}} / Q_{\mathrm{H}_{2}}-1\right) /(1 / 2)\left(Q_{\mathrm{H}_{1}} / Q_{\mathrm{H}_{2}}+1\right), Q_{\mathrm{H} 1}=F_{\mathrm{H} 1} / \overline{F_{\mathrm{H}}} ;$

$\mathrm{H}_{1}$, Bijvoet reflection; $\mathrm{H}_{2}$, reference reflection.

as those for $F_{0^{-}}$data collection previously described except for the scan speed $\left(2^{\circ} \mathrm{min}^{-1}\right.$ in $\left.2 \theta\right)$ and background counting time $(20 \mathrm{~s})$. The results of the measurement are summarized in Table III. The absolute configuration of the metabolite is correctly represented by the atomic coordinates in Tables 1 and 2 referring to a right-handed coordinate system. The probability that the assigned absolute configuration is wrong is estimated to be 0.03 assuming $t$-distribution of $D E L A$ 's. ${ }^{4)}$ Atomic scattering factors were taken from the International Tables for X-Ray Crystallogarlphy. ${ }^{6)}$

\section{RESULTS AND DISCUSSION}

A computer generated perspective drawing of the molecular structure is shown in Fig. 1 with the numbering scheme of atoms used in this paper. The bond lengths and angles are given in Table 4: they are consistent with the formula I. The present compound is identical with naphthalic anhydride obtained by oxidizing atrovenetin with alkaline peroxide. This compound was also isolated from Penicillium herquei. $\left.{ }^{7}{ }^{8}\right)$ The configuration at $\mathrm{C}(9)$ determined by the present $\mathrm{X}$-ray analysis agrees with that shown by the chemical study. ${ }^{\text {g) }}$
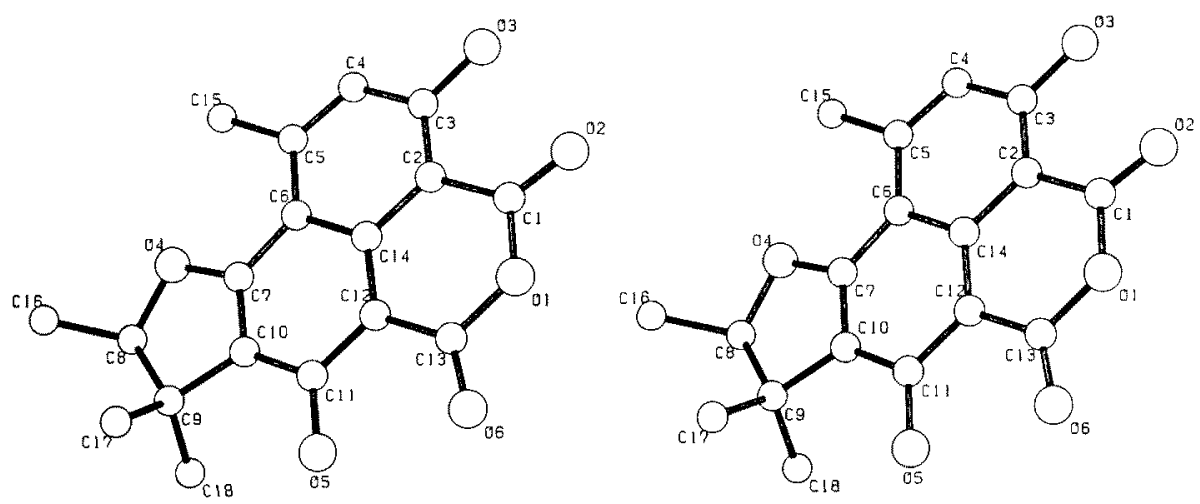

Fig. 1. Molecular Structure and Numbering Scheme.

This figure was drawn by PLUTO ${ }^{10)}$ and shows the correct absolute configuration. 
Table IV. Bond Lengths and Angles

\begin{tabular}{|c|c|c|c|}
\hline \multicolumn{4}{|c|}{ (a) Bond lengths $(\AA)$} \\
\hline$C(1)-C(2)$ & $1.459(10)$ & $C(1)-O(1)$ & $1.370(9)$ \\
\hline$C(1)-O(2)$ & $1.203(10)$ & $C(2)-C(3)$ & $1.378(9)$ \\
\hline$C(2)-C(14)$ & $1.431(9)$ & $C(3)-C(4)$ & $1.381(10)$ \\
\hline$C(3)-O(3)$ & $1.348(9)$ & $C(4)-C(5)$ & $1.356(10)$ \\
\hline$C(5)-C(6)$ & $1.435(9)$ & $C(5)-C(15)$ & $1.523(12)$ \\
\hline$C(6)-C(7)$ & $1.427(9)$ & $C(6)-C(14)$ & $1.422(8)$ \\
\hline$C(7)-C(10)$ & $1.350(9)$ & $\mathrm{C}(7)-\mathrm{O}(4)$ & $1.348(8)$ \\
\hline$C(8)-C(9)$ & $1.564(10)$ & $C(8)-C(16)$ & $1.572(14)$ \\
\hline $\mathrm{C}(8)-\mathrm{O}(4)$ & $1.463(8)$ & $\mathrm{C}(9)-\mathrm{C}(10)$ & $1.549(10)$ \\
\hline $\mathrm{C}(9)-\mathrm{C}(17)$ & $1.513(13)$ & $C(9)-C(18)$ & $1.528(11)$ \\
\hline$C(10)-C(11)$ & $1.384(9)$ & $C(11)-C(12)$ & $1.426(10)$ \\
\hline$C(11)-O(5)$ & $1.316(10)$ & $C(12)-C(13)$ & $1.434(11)$ \\
\hline$C(12)-C(14)$ & $1.397(9)$ & $C(13)-O(1)$ & $1.395(9)$ \\
\hline$C(13)-O(6)$ & $1.225(10)$ & & \\
\hline \multicolumn{4}{|l|}{ (b) Bond angles $\left({ }^{\circ}\right)$} \\
\hline$C(2)-C(1)-O(1)$ & $117,4(6)$ & $\mathrm{C}(2)-\mathrm{C}(1)-\mathrm{O}(2)$ & $125.0(7)$ \\
\hline $\mathrm{O}(1)-\mathrm{C}(1)-\mathrm{O}(2)$ & $117.6(7)$ & $C(1)-C(2)-C(3)$ & $120.3(6)$ \\
\hline$C(1)-C(2)-C(14)$ & $119.1(6)$ & $C(3)-C(2)-C(14)$ & $120.4(6)$ \\
\hline$C(2)-C(3)-C(4)$ & $120.4(6)$ & $\mathrm{C}(2)-\mathrm{C}(3)-\mathrm{O}(3)$ & $122.3(6)$ \\
\hline$C(4)-C(3)-O(3)$ & $117.3(6)$ & $C(3)-C(4)-C(5)$ & $122.1(7)$ \\
\hline$C(4)-C(5)-C(6)$ & $119.5(6)$ & $C(4)-C(5)-C(15)$ & $120.6(7)$ \\
\hline$C(6)-C(5)-C(15)$ & $119.9(6)$ & $C(5)-C(6)-C(7)$ & $126.4(6)$ \\
\hline$C(5)-C(6)-C(14)$ & $119.5(6)$ & $C(7)-C(6)-C(14)$ & $114.0(5)$ \\
\hline$C(6)-C(7)-C(10)$ & $124.6(6)$ & $C(6)-C(7)-O(4)$ & $121.4(5)$ \\
\hline$C(10)-C(7)-O(4)$ & $114.0(5)$ & $C(9)-C(8)-C(16)$ & $115.2(7)$ \\
\hline $\mathrm{C}(9)-\mathrm{C}(8)-\mathrm{O}(4)$ & $107.2(5)$ & $C(16)-C(8)-O(4)$ & $104.2(6)$ \\
\hline$C(8)-C(9)-C(10)$ & $98.8(5)$ & $C(8)-C(9)-C(17)$ & $113.8(7)$ \\
\hline$C(8)-C(9)-C(18)$ & $108.0(6)$ & $C(10)-C(9)-C(17)$ & $111.0(7)$ \\
\hline$C(10)-C(9)-C(18)$ & $112.2(6)$ & $C(17)-C(9)-C(18)$ & $112.4(7)$ \\
\hline$C(7)-C(10)-C(9)$ & $110.0(6)$ & $C(7)-C(10)-C(11)$ & $121.5(6)$ \\
\hline$C(9)-C(10)-C(11)$ & $128.5(6)$ & $C(10)-C(11)-C(12)$ & $116.9(6)$ \\
\hline$C(10)-C(11)-O(5)$ & $120.4(7)$ & $\mathrm{C}(12)-\mathrm{C}(11)-\mathrm{O}(5)$ & $122.6(7)$ \\
\hline$C(11)-C(12)-C(13)$ & $118.2(7)$ & $C(11)-C(12)-C(14)$ & $121.3(6)$ \\
\hline$C(13)-C(12)-C(14)$ & $120.5(6)$ & $C(12)-C(13)-O(1)$ & $117.5(6)$ \\
\hline$C(12)-C(13)-O(6)$ & $126.2(7)$ & $\mathrm{O}(1)-\mathrm{C}(13)-\mathrm{O}(6)$ & $116.4(7)$ \\
\hline$C(2)-C(14)-C(6)$ & $118,0(5)$ & $C(2)-C(14)-C(12)$ & $120.4(6)$ \\
\hline$C(6)-C(14)-C(12)$ & $121.7(6)$ & $C(1)-O(1)-C(13)$ & $125.1(6)$ \\
\hline$C(7)-O(4)-C(8)$ & $108.1(5)$ & & \\
\hline
\end{tabular}

There are two intramolecular hydrogen bonds between hydroxyl groups and carbonyl oxygen atoms; the distances of $\mathrm{O}(2)---\mathrm{H}(\mathrm{O} 3)$ and $\mathrm{O}(6)---\mathrm{H}(\mathrm{O} 5)$ are 1.90 and $1.84 \AA$, respectively, and the angles of $O(3)-$ $\mathrm{H}(\mathrm{O} 3)--\mathrm{O}(2)$ and $\mathrm{O}(5)-\mathrm{H}(\mathrm{O} 5)--\mathrm{O}(6)$ are $135^{\circ}$ and $132^{\circ}$.

Except for the three methyl groups bonded to the five membered ring, all non-hydrogen atoms are coplanar; the rms deviation of these atoms from the best plane is $0.043 \AA$. The molecule is arranged with its plane perpendicular to the crystallographic $b$ axis with an interplanar distance of $3.4 \AA$. There is neither intermolecular hydrogen bonds nor abnormally short contact.
Acknowledgments. We wish to thank Professor Masao Kakudo of the Institute for Protein Research, Osaka University, for permission to use the Rigaku four-circle diffractometer. This work was supported in part by a Grant-in-Aid for Cancer Research (53-2) from the Ministry of Health and Welfare, and by a Research Grant from the Ministry of Education of Japan.

\section{REFERENCES}

1) K. Fukuyama, Y. Katsube, A. Noda, T. Hamasaki, and Y. Hatsuda, Bull. Chem. Soc. Japan, 51, 3175 (1978).

2) G. Germain, P. Main, and M. M. Woolfson, 
Acta Cryst., A27, 368 (1971).

3) T. Ashida, HBLS-V, The Universal Crystallographic Computing System-Osaka, The Computation Center, Osaka University, (1973).

4) D. W. Engel, Acta Cryst., B28, 1496 (1972).

5) K. Fukuyama, K. Hamada, T. Tsukihara, and $Y$. Katsube, Bull. Chem. Soc. Japan, 51, 37 (1978).

6) "International Tables for X-Ray Crystallography" Vol. IV, Kynoch Press, Birmingham (1974).
7) D. H. R. Barton, P. de Mayo, G. A. Morrison, and H. Raistrick, Tetrahedron, 6, 48 (1959).

8) N. Narasimhachari and L. C. Vining, Can. J. Chem., 41, 641 (1963).

9) J. S. Brooks and G. A. Morrison, Chem. Comm., 1971, 1359.

10) S. Motherwell, PLUTO, a Program for Plotting Molecular and Crystal structures, Cambridge Crystallographic File User Manual, May 1976. 